\title{
Barriers Associated With Pain Management among Patients with Advanced
}

\section{Breast Cancer}

\author{
Joan Chepkemei Maiyo, Professional Nurse \\ Moi Teaching and Referral Hospital, Eldoret, Kenya
}

\author{
Sanaa Mohamed Alaa Eldin, Professor \\ Medical Surgical Nursing, Faculty of Nursing, Alexandria University \\ Rasha Aly Yakout, Assistant Professor \\ Medical Surgical Nursing, Faculty of Nursing, Alexandria University
}

\begin{abstract}
Cancer is a cause of morbidity and mortality in Kenya. A patient diagnosed with advanced breast cancer has to live with a chronic disease faced with structural, physiological and psychological, as well as socioeconomic challenge. Appropriate pain assessment and management are key indicators of pain care quality and patients satisfaction, regardless of health care setting. Inadequate pain management can be attributed to barriers related to health care professionals, patient, health care system, medication and sociocultural barriers. Objective: Identify barriers associated with pain management among patients with advanced breast cancer. Setting: The study was conducted at the Chandaria Cancer and Chronic Disease Center (CCCDC) at Moi Teaching and Referral Hospital in Kenya. Subjects: A purposive sample of 115 female patients diagnosed with stage III or stage IV Advanced Breast Cancer (ABC) from the CCCDC outpatient clinic, was included in the study. Tools: Two tools were used for data collection; Advanced Breast Cancer Pain Management Barriers Structured Interview Schedule (ABCPMIS) and Visual analog scale (VAS). Results: The study implies that patient related barriers and sociocultural barriers are the most prevalent barriers to pain management in advanced breast cancer patients attending the CCCDC. There were significant statistical differences between levels of barriers experienced and patients' current status of disease, seeking of medical advice when in pain and their reported VAS levels. Conclusion: Patients with advanced breast cancer face various barriers to pain management related to their patient characteristics, sociocultural factors and system barriers in the health care systems. Recommendation: Implementing supportive and clinical pain management programs to advanced breast cancer patients to alleviate the pain and suffering is recommended.
\end{abstract}

Keywords: Advanced Breast Cancer; Pain; Barriers.

\section{Introduction}

Cancer being a systemic disease, causes cells in the body to change and grow out of control ${ }^{(1)}$. Breast cancer currently, is the most common cancer among women ${ }^{(2)}$. It is a malignant tumor that starts in the cells of the breast and the cancer cells attach to any tissue in the body. The most common sites for metastases include the bones, skin, lymph nodes, lungs, liver and the brain ${ }^{(3)}$. The American Cancer Society's estimates for breast cancer for 2016 new cases are 246,660 of invasive breast cancer, 61,000 of carcinoma in situ (CIS) and 40,450 deaths from breast cancer ${ }^{(4)}$. Cancer is the $3^{\text {rd }}$ highest cause of morbidity in Kenya after infectious diseases and cardiovascular diseases. The incidence of breast cancer being 34 per $100,000^{(5)}$.

Most cases diagnosed in the developing countries are in more advanced stages of the disease, which complicates treatment and many barriers in its diagnosis and treatment remain rampant ${ }^{(6)}$. The prognosis of invasive breast cancer is strongly influenced by the stage of the disease which includes stage (0) noninvasive, stage (1) carcinoma in situ tumor $<2 \mathrm{~cm}$ and no evidence of metastases, stage (2) tumor still in the breast or extended only to nearby lymph nodes. Advanced breast 
cancer (ABC) is mainly, stages (3) and (4). Stage (3) is locally advanced breast cancer, which means the cancer has spread to lymph nodes and/or other tissue in the breast, but not to further sites in the body(5). Stage (4) is metastatic breast cancer; the cancer has spread to other sites of the body ${ }^{(7)}$.

Treatment for advanced breast cancer, is essentially based on chemotherapy, hormonal therapy and targeted therapies ${ }^{(3)}$. Radiotherapy and surgery are sometimes needed for symptomatic treatment to control pain, improve quality of life and increase tolerance to treatment ${ }^{(1)}$. These various therapies may be given alone, in combination or one after the other, depending on the characteristics of each tumor, previous treatments and are unique to each person ${ }^{(8,9)}$. These treatment strategies are decided by a team, and the patient's opinion taken into consideration, as it involves a whole series of treatments ${ }^{(7)}$.

Pain is defined as an unpleasant sensory and emotional experience associated with actual or potential tissue injury. Management of pain is key in patient care, that it is referred to as "the fifth vital sign" ${ }^{(10,11)}$. American Pain Society standards state that "pain is assessed in all patients" and that "patients have the right to appropriate assessment and management of pain"(10). A number of factors, including past experiences with pain, anxiety, culture, age, gender, genetics, and expectations about pain relief, influence the patients' experience of pain. These factors may increase or decrease opinion, tolerance, and affect reactions to pain ${ }^{(11)}$. The pain may result from direct tumor invasion of local tissues, compression or invasion of nerves, metastasis into bone, visceral obstruction, or after disease directed primary therapy i.e. chemotherapy, radiotherapy, or surgery ${ }^{(8,12)}$.

High prevalence of advanced breast cancer pain and often unfortunate failure to relieve it has resulted in great attention to the barriers that persist. Studies done by Meredith (2013), Shute (2013) and Jacobsen $(2009)^{(6,13,14)}$ have continually documented that, patients play a key role in pain management. Some patients may be reluctant to report their pain for reasons including fear of side effects, fatalism about the possibility of achieving pain control, health care professionals attitude and belief that pain is indicative of progressive disease $^{(13,14)}$. There are also significant health care professional barriers to adequate pain relief. Physicians, nurses, and other members of the interdisciplinary team often fail to adequately assess the patient's pain or to be abreast of patient barriers ${ }^{(15)}$.

On the other hand system barriers include legal and regulatory structures that hinder the provision of optimal care as well, as inadequate reimbursement for pain services ${ }^{(16,17)}$. Pharmacological management is the pillar of pain management according to assessment of pain severity ${ }^{(18)}$. Appropriate use of nonopioids, opioids, and adjuvant analgesics, along with a variety of anticancer therapies allows for great strides in managing cancer-related pain if properly applied $^{(18)}$. Additionally sociocultural barriers include, lack of family support, other medical and emotional problems, e.g. physical symptoms burden, body image disturbance, and disrupted daily activities, fear of diagnosis and interventions, feelings of anguish and helplessness, and caring for a sick family member ${ }^{(19)}$.

The American Nurses Association published standards that indicated that nurses must document assessment of patient's pain in the medical record ${ }^{(10)}$. Assessment of pain includes determining the level of pain relief, that is needed to recuperate quickly or improve function, and to maintain comfort ${ }^{(20)}$. Part of a thorough pain assessment includes, assessing the patient's anticipations and misconceptions about pain and addressing them. The nurse should understand that pain relief not only contributes to comfort but also hastens recovery hence administers treatment appropriately $^{(21,22)}$. 


\section{Aim of the Study}

This study aimed to identify barriers associated with pain management among advanced breast cancer patients.

\section{Research Question:}

What are the barriers associated with pain management among advanced breast cancer patients?

\section{Materials and Method}

\section{Materials}

Design: A descriptive research design was utilized for this study.

Setting: The study was conducted at the Chandaria Cancer and Chronic Disease Center (CCCDC) at Moi Teaching and Referral Hospital Kenya. The CCCDC serves as an outpatient clinic for several diseases. This includes the oncology clinic which is an outpatient clinic that operates from Monday to Friday, from $8 \mathrm{am}-5 \mathrm{pm}$ with an approximate number of 1200 patients per month. Every Tuesday of the week is a breast cancer clinic day where most patients with breast cancer are seen in addition to the other days of the week. Approximately $300-500$ patients with breast cancer are seen in a month.

Subjects: A systematic random sample of 115 female based on Epi info 7 which was used to estimate the minimum sample size. The female patients were considered eligible to participate in the study if they met the following criteria:

- Adult female patients aged from 21 60 years and able to communicate verbally.

- Diagnosed with histologically proven clinical stage III and/stage IV or inflammatory breast cancer.

- Have been informed of their diagnosis of breast cancer.

- Have ongoing treatment for stage III/stage IV of breast cancer i.e. chemotherapy, radiation and postsurgical interventions.
Tools: Two tools were used for data collection:

Tool I: Advanced Breast Cancer Pain Management Barriers Structured Interview Schedule (ABCPMSIS)

This tool was developed by the researcher based on relevant literature review $^{(23-25)}$ to explore barriers associated with pain management among advanced breast cancer patient. It includes two parts:

\section{Part I: Socio demographic data:}

\section{a. Socio-demographic} characteristics: Patient's residence, age, marital status, living arrangements, level of education, religion, occupation, health insurance, and income.

b. Patient's clinical history data such as: stage of disease, current status of disease, onset of disease, previous and current treatment, characteristic of pain, date associated with symptoms occurrence/reason for seeking treatment, and pain rating.

Part II: Pain Management Interview Schedule (PMIS):

The PMIS was developed by the researcher based on relevant literature review $^{(23,24)}$ to explore patient's responses on barriers to pain management, which included 5 categories of barriers:

I. Health Care Professional Related Barriers included nine barriers: waiting list, pain assessment, management of pain, time taken to be reviewed by the medical professionals, talking about pain, endurance of pain, and information on pain medication side effects, management of medication side effects, and consultation to supportive care by the medical professionals.

II. Patient Related Barriers included ten barriers: financial, transport, locating the referral facility, reporting of pain, worries about 
pain, personal beliefs, long term use of opioids, information about pain medication, shame of being on treatment regularly, refusing to take opioids and time off work or school.

III.System barriers included seven barriers: availability of morphine, issuance of drugs in the pharmacy, pain medication prescriptions, accessibility, review by different doctors, schedule visit and the nurse patient ratio.

IV. Medication barriers included nine barriers: effect of prescribed dose, side effects, reporting of side effects, and management of side effects, addiction, and tolerance, attitude about opioids, alternative medicine and severity of pain.

V. Sociocultural barriers included ten barriers: role of family, taking care of a sick family member, attitude of friends and family members, negative public image of morphine, seeking medical advice is against religion, society influence, traditional herbal medicine, previous experiences of friends and cultural beliefs to talk about pain.

Scoring system: Each patients' responses for each item was scored on a 3 point Likert scale ranging from "Always (3 scores)", "sometimes (2 scores)" and "never (1 score)".

The total and subtotal scores were calculated and converted into percentage scores. A score of $>65 \%$ represent high barriers, scores of $65-45 \%$ represent moderate barriers and scores of $<45 \%$ represent low barriers ${ }^{(26)}$.

\section{Tool II: Visual analog scale (VAS)}

This is a standardized pain assessment tool used to measure pain intensity among advanced breast cancer patients adapted from Klimek et al. $(2017)^{(27)}$. It is a single-item scale and using a ruler, the score was determined by measuring the distance $(\mathrm{mm})$ on the $10-\mathrm{cm}$ line between the "no pain" anchor and the patient's mark, providing a range of scores from 0-10. Mild pain (1-3), moderate pain (4-7), and severe pain (8-10).

\section{Method}

- Official approval to conduct the study was obtained from the relevant authorities in Kenya.

- Two tools were used for data collection; Tool I: Advanced Breast Cancer Pain Management Barriers Structured Interview Schedule (ABCPMBSIS) and Tool II: the Visual Analogue Scale (VAS).

- Tool I was tested for content validity by five experts in the field of MedicalSurgical faculty of Nursing Alexandria University and also verified for its reliability using Cronbach's coefficient Alpha statistical test for internal consistency of the tool items. The data was analyzed; the correlation coefficient was $(\alpha=0.8)$

- Before embarking on the actual study, a pilot study was carried out to test the feasibility and applicability of the developed tool of the study sample. It was applied on $10 \%$ (11) female patients who met the inclusion criteria at CCCDC in MTRH. Data obtained was excluded from the study.

- After securing administrative approval, data collection was started which covered a period of 4 months from May 2017 to August 2017. Data was collected four days per week from 9am to $4 \mathrm{pm}$.

- The files of patients presenting to the Oncology clinic were screened for eligibility.

- Every patient who gave consent to participate in the study was assessed for presence of pain or not using Tool II.

- Every patient was interviewed on a face to face basis for 30 - 45 minutes in the outpatient clinic using Tool I. The interview was done in an allocated room 
by the department to collect the necessary data.

\section{Ethical considerations:}

Written informed consent was obtained from each female patient after explanation of the purpose of the study. Privacy and anonymity of the female patients was also ascertained.

\section{Statistical Analysis}

Statistical Package for Social Sciences (SPSS version 17.0) for windows was used for data analysis. The 0.05 level was used as the cut off value for statistical significance. Chi square $\left(\mathrm{x}^{2}\right)$ was used to test the associations between two qualitative variables or to detect difference between two or more proportions. Fisher's Exact test and Monte Carlo was used whenever the expected frequency in any of the cells of $2 \times 2$ tables falls below $5^{(28)}$.

\section{Results}

Table (1) shows the distribution of the studied patients according to their bio socio demographic data. The study revealed that (56.6\%) of the studied patients were 40-50 years old, $44.3 \%$ were married while 22.6 $\%$ were widowed. More than one third $44.3 \%$ had high school education, and majority $93.9 \%$ were Christians. Concerning employment status, most patients were unemployed $62.6 \%$, majority of them $97.9 \%$ had National Hospital Insurance Fund (NHIF) and more than half $57.4 \%$ had sufficient monthly income.

Table (2) represents the clinical data of the studied patients. In relation to stage of disease, majority of the patients $67 \%$ presented with stage 4 . Regarding current status of disease $45.2 \%$ of the patients were under treatment, while $42.6 \%$ of them had recurrent breast cancer after surgical intervention (mastectomy, breast conserving surgery), but were under treatment. In relation to previous treatment, more than half of patients $58.3 \%$, had surgery previously while $22.6 \%$ had undergone chemotherapy, and $17.4 \%$ had taken herbal medication for example tree barks of local confetti and the pepper-wood trees, the latter known as "Mkaa" in Kiswahili, least of them $1.7 \%$ having undergone radiotherapy. Regarding current status of disease majority of the patients $94.8 \%$ were on chemotherapy.

Concerning suffering from pain and seeking medical advice when in pain, majority of the patients $98.3 \%$ were in pain, $60 \%$ sought medical advice, $41.7 \%$ came immediately to the clinic when in pain, while $18.3 \%$ waited for the scheduled visit. According to the Visual Analogue Scale (VAS) more than one third of the patients $49.6 \%$ reported severe pain and $47.8 \%$ moderate pain while $2.6 \%$ had mild pain.

Table (3a) shows health care professional and patient related barriers of the studied patients. As regards to health care professional barriers majority of the patients $70.4 \%$ reported that they always had to wait for a scheduled consultation. In relation to information on side effects of pain medication $80 \%$ of the patients reported that sometimes information was given by nurses or doctors and $94.8 \%$, of the patients never had problems talking about pain while $96.5 \%$ never endured pain before resorting to a pain relief measure.

Concerning patient related barrier, the table revealed that $91.3 \%$ were always worried of pain being a sign that the illness has gotten worse and a similar percentage 91.3\% were worried always of the long term use of pain medication. More than half of the patients $59.1 \%$ reported that "sometimes" they had difficulty understanding information on pain medication and $55.7 \%$ never believed that, enduring pain is better than losing the breast.

Table (3b) reveals system and medication related barriers of the studied patients. The table demonstrates that the most prevalent system barriers as reported by majority of patients $94.8 \%$ was always being reviewed by different doctors during schedule clinic visit, while $31.3 \%$ of the patients reported that "sometimes" time allocated to their pain needs was not enough 
and all patients reported that they were never denied the prescribed medications.

Regarding medication barriers the table conveyed that $90.4 \%$ were always worried of getting addicted to pain medicine and $89.6 \%$ reported that, always the side effects of the pain medications are difficult to control.

Furthermore most patients $49.6 \%$ reported that sometimes when in pain they were relieved by the prescribed pain medication dose, while $99.1 \%$ reported that pain medication never blocked their ability to know if they had new pain.

Table (3c) sociocultural barriers associated with pain management of the studied patients. Regarding socio cultural barrier, the results showed that $96.6 \%$ of the patients always reported that people around them always believe if you have cancer, you should not go for treatment and also a similar percentage reported that their communities believed in traditional herbal medicine than seeking treatment. On the other hand, more than one third of the patients $38.3 \%$ reported that sometimes they had a sick family member to take care of preventing them from attending the clinic. The results also revealed that the majority of the patients $81.8 \%$ reported that family/friends never made fun of them when they complained about pain.

Table (4) shows Mean, standard deviation of barriers associated with pain management of the studied female patients. The results revealed that patient related barriers had the highest mean and standard deviation $(67.1 \pm 10.9)$ and sociocultural barriers (67.1 \pm 9.7$)$ respectively while medication barriers had the lowest mean and standard deviation (58.5 \pm 8.9$)$. High scores were reported in patient related barriers $(60.9 \%)$ medication barriers had moderate scores (72.2\%), while sociocultural barriers (53.9\%) also had high scores.

Table (5) illustrates relation between Bio socio-demographic characteristics and the level of barriers experienced by the studied female patients.

The table illustrated that there was statistical significant differences between level of barriers experienced and educational level and monthly income where $\mathrm{P}=0.036, \mathrm{P}=0.006$ respectively.

Table (6) denotes the relation between level of barriers experienced and the clinical characteristics of the studied female patients. The table denoted that there was statistically significant differences between levels of barriers experienced and stage of disease, patients current status of disease, seeking medical advice when in pain and VAS where $\mathrm{P}<0.0006, \mathrm{P}<0.0001, \mathrm{P}=0.006$, $\mathrm{P}<0.0001$ respectively.

\section{Discussion}

Breast cancer incidence in sub-Saharan Africa is on the rise. Advanced Breast cancer is an important health challenge that women face and affect their safety and productivity ${ }^{(29)}$. Often, owing to poor access to healthcare services, it presents late and tumors are often inoperable. This gives rise to a burden of pain associated with tumor growth that is rarely present in countries with more developed healthcare systems ${ }^{(30)}$. In Kenya, most cancers are often diagnosed at the advanced stages of the disease. A patient diagnosed with advanced breast cancer has to live with a chronic disease faced with structural, physiological and psychological, as well as socioeconomic challenges ${ }^{(5)}$.

Results of the current study revealed that, more than half of the sample was aged between 40 to less than 50 years. Similar results were reported in a study done in Egypt by Ismail et al. (2013) ${ }^{(29)}$ to assess factors that hinder early detection of breast cancer among females at Cairo University Hospital. Moreover in agreement with the research results of the American Cancer Society $(2017)^{(31)}$ which revealed that, the risk of developing breast cancer increases with advanced age. In relation to stage of disease, majority of the studied patients presented with stage (4) breast cancer. This 
is in line with findings of Eldoret Cancer Registry $^{(5)}$ that late presentation of breast cancer remains high with at least $90 \%$, of the cases presenting with Stage 3 or 4 disease at Moi Teaching and Referral Hospital (MTRH) in Kenya. In a study done in Malaysia, similar findings were reported, where majority of Malaysian women in Segamat Hospital were diagnosed with breast cancer at stage (3) and stage (4) ${ }^{(32)}$.

Regarding results of the Visual Analogue Scale (VAS); most of the studied patients had severe pain and a few of them had moderate pain. Similar results were reported in a study done by Hughes et al. $(2017)^{(30)}$ which showed a high incidence of breast pain in patients with advanced cancer. Moreover, a study that was carried out by Kwon $(2014)^{(33)}$, found that a patient who has concerns and misconceptions about pain medications may be reluctant to report pain and take opioids. Other potential barriers from the patient perspective reported in various studies include miscommunication with physicians (underreporting of symptoms to avoid distracting physician from providing cancer treatments), misconceptions regarding pain medicine (fear of adverse effects, addiction, tolerance, and lowered immunity caused by pain medicine), and fatalistic beliefs (inevitably, uncontrollability, and idea that increasing pain indicates disease progression $)^{(33,26,34)}$. These findings are consistent with the present study results, in which the most commonly reported patient related barrier, was "worries of pain being a sign that the illness has gotten worse and long term use of pain medication".

Regarding system barriers, most prevalent was "review by different doctors" during the scheduled clinic visit. Consistent with the results by Jacobsen et al. (2009) ${ }^{(25)}$ who found that there are problems related with continuity of care, when the patient is seen by a number of different physicians across a number of different health care settings with no one capable or willing to take responsibility for the overall pain management. The present study results revealed that the most cited of medication barriers was fear of addiction and believing that side effects of pain medications could not be mitigated. This concurs with other studies in developing countries, with similar results. According to a meta-analysis done in Malaysia almost every patient interviewed was observed to express fear towards the procedure of surgery and side effects of chemotherapy (Norsa'adah et al., 2012) ${ }^{(35)}$.

Breast cancer diagnosis affects both patient and family in many different ways because a cancer diagnosis implies death, uncertainty, and loss of control ${ }^{(14)}$. Most prevalent of the sociocultural barriers reported by the studied patients, was "People believe if you have cancer you should not go for treatment", "community believe in traditional herbal medicine than seeking treatment" and "friends advised you not to go for treatment because of their previous experiences with pain medications and family had a role in pain management. This is in agreement with a study done in Malaysia on understanding barriers to Malaysian women with breast cancer seeking help. They found that, middle aged women in Malaysia, regardless of any ethnic, educational and social background were found lacking self-management and often required family member or friend for support regarding their treatment choice Norsa'adah et al. (2012) ${ }^{(35)}$.

The results of the current study revealed that patient related barriers and sociocultural barriers had the highest means respectively while medication barriers had the lowest mean. These findings contrast strikingly with a study done by Bourdeanu et al. (2013) $)^{(26)}$ where only minority of patients were found to have patient-related barriers, with the most cited reason why women waited to seek medical attention being fear of being diagnosed with cancer. These fears continue to cause major barriers for patients. Moreover, findings of the current study show that the patient population experienced fewer system barriers. 
The socioeconomic status of breast cancer patients has a significant impact on prognosis through its associated influence on the cancer stage at diagnosis. Previous findings suggest people with lower incomes have a late cancer stage at point of diagnosis and a worse overall prognosis ${ }^{(36)}$. A study done by Wang et al. (2012) $)^{(37)}$, found that socioeconomic status is also significantly associated with education level and occupation, both of which can greatly influence patients' perception of the tumor, thereby affecting the level of early detection, diagnosis, and treatment. This is in line with the present results in which there were a significant statistical difference between level of barriers experienced and educational level and sufficiency of monthly income.

Early identification of patients at increased risk of experiencing high levels of pain could facilitate targeted pain and palliative care assessment and the implementation of a comprehensive treatment plan to reduce the most severe and persistent symptoms ${ }^{(22)}$. In the present study, there was statistical significant difference between levels of barriers experienced and patient's current status of disease, seeking medical advice when in pain and VAS. Similar results were reported in a study by (Stuver, et al. 2016) ${ }^{(38)}$ that pain is a prevalent symptom among ambulatory patients with advanced cancer. Severe pain was associated with younger age, minority race, and recent onset of advanced disease.

This study documents a high prevalence of advanced breast cancer pain. There are also a high proportion of patients getting inadequate pain management. This study reflects the management and barriers of advanced breast cancer pain in the public health system since Moi Teaching and Referral Hospital in Kenya is one of the only two public hospitals in the country offering oncology services. These findings suggest that patient's perceptions and beliefs of the society, to include friends' comments, serve as barriers to treatment.
These results indicate that system and physician barriers are not as prevalent as reported in other studies ${ }^{(26)}$.

In addition the statistical significant relationship between level of barriers experienced with education level, sufficiency of monthly income and stage of disease could be attributed to lack of knowledge and fear of treatment outcomes. Hence, although it is important to continue to address the physician and system barriers, a need exists to direct greater resources toward educating patients and the population about the importance of assertively seeking early medical assessment, and to share information about the significant advances yielding improved survival and quality of life outcomes, so that patients, family, and society can overcome the fear of treatment ${ }^{(39)}$. Nurses therefore play a role in addressing patient and family issues, related to pain and formulate plans of care and research agendas to effectively manage pain.

\section{Conclusion}

Patients with Advanced Breast Cancer face various barriers to pain management related to their patient characteristics, sociocultural factors and system barriers in the health care systems.

\section{Recommendation}

Implementing supportive and clinical pain management programs to patients with breast cancer to alleviate the pain and suffering is recommended. 
Table (1): Socio-demographic characteristics of the studied patients $(n=115)$

\begin{tabular}{|c|c|c|}
\hline Bio Socio-demographic characteristics & No. & $\%$ \\
\hline $\begin{array}{l}\text { Age (years) } \\
20-<30 \\
30-<40 \\
40-<50 \\
50-\leq 60\end{array}$ & $\begin{array}{c}2 \\
20 \\
\mathbf{6 5} \\
28\end{array}$ & $\begin{array}{c}1.7 \\
17.4 \\
\mathbf{5 6 . 6} \\
24.3\end{array}$ \\
\hline $\begin{array}{l}\text { Marital status } \\
\text { Single } \\
\text { Married } \\
\text { Divorced } \\
\text { Widow }\end{array}$ & $\begin{array}{l}23 \\
\mathbf{5 1} \\
15 \\
26\end{array}$ & $\begin{array}{l}20.1 \\
\mathbf{4 4 . 3} \\
13.0 \\
22.6\end{array}$ \\
\hline $\begin{array}{l}\text { Educational level } \\
\text { Illiterate } \\
\text { Primary education } \\
\text { High school } \\
\text { College/ Graduate }\end{array}$ & $\begin{array}{l}12 \\
22 \\
51 \\
30\end{array}$ & $\begin{array}{l}10.4 \\
19.2 \\
44.3 \\
26.1\end{array}$ \\
\hline $\begin{array}{l}\text { Religion } \\
\text { Muslim } \\
\text { Christian } \\
\text { Others }\end{array}$ & $\begin{array}{c}2 \\
108 \\
5\end{array}$ & $\begin{array}{c}1.7 \\
93.9 \\
4.4\end{array}$ \\
\hline $\begin{array}{l}\text { Employment status } \\
\text { Employed } \\
\text { Not employed } \\
\text { Unemployed } \\
\text { Retired }\end{array}$ & $\begin{array}{c}39 \\
76 \\
72 \\
4\end{array}$ & $\begin{array}{l}33.9 \\
66.0 \\
\mathbf{6 2 . 6} \\
3.5\end{array}$ \\
\hline $\begin{array}{l}\text { Have health insurance } \\
\text { Yes } \\
\text { No }\end{array}$ & $\begin{array}{l}98 \\
17\end{array}$ & $\begin{array}{l}\mathbf{8 5 . 2} \\
14.8\end{array}$ \\
\hline $\begin{array}{l}\text { Type of insurance [n=98] } \\
\text { If Yes } \\
\text { National Hospital Insurance Fund } \\
\text { Private insurance }\end{array}$ & $\begin{array}{c}96 \\
2\end{array}$ & $\begin{array}{c}\mathbf{9 7 . 9} \\
2.1\end{array}$ \\
\hline $\begin{array}{l}\text { Sufficiency of monthly income } \\
\text { Insufficient } \\
\text { Sufficient } \\
\text { More than sufficient }\end{array}$ & $\begin{array}{c}48 \\
66 \\
1\end{array}$ & $\begin{array}{c}41.7 \\
\mathbf{5 7 . 4} \\
0.9\end{array}$ \\
\hline
\end{tabular}


Table (2): Percentage distribution of the studied patients according to their clinical data $(\mathrm{n}=\mathbf{1 1 5})$

\begin{tabular}{|c|c|c|}
\hline Clinical data & Number & Percentage score \\
\hline \multicolumn{3}{|l|}{ Stage of disease } \\
\hline Stage III & 8 & 7.0 \\
\hline Stage IV & 77 & 67.0 \\
\hline Inflammatory & 30 & 26.0 \\
\hline \multicolumn{3}{|l|}{ Current status of disease } \\
\hline Newly diagnosed & 9 & 7.8 \\
\hline Under treatment & 52 & 45.2 \\
\hline Recurrent under treatment & 49 & 42.6 \\
\hline Others(Herbal medication & 5 & 4.4 \\
\hline \multicolumn{3}{|l|}{ Previous treatment } \\
\hline Surgery & 67 & 58.3 \\
\hline Chemotherapy & 26 & 22.6 \\
\hline Radiotherapy & 2 & 1.7 \\
\hline Herbal medicine & 20 & 17.4 \\
\hline \multicolumn{3}{|l|}{ Current treatment } \\
\hline Chemotherapy & 109 & 94.8 \\
\hline Radiotherapy & 3 & 2.6 \\
\hline Both & 3 & 2.6 \\
\hline \multicolumn{3}{|l|}{ Visual analogue scale } \\
\hline Mild pain & 3 & 2.6 \\
\hline Moderate pain & 55 & 47.8 \\
\hline Severe pain & 57 & 49.6 \\
\hline \multicolumn{3}{|l|}{ Suffering from pain } \\
\hline No & 3 & 2.6 \\
\hline Yes & 113 & 98.3 \\
\hline \multicolumn{3}{|c|}{ Seek medical advice when in pain } \\
\hline No & 46 & 40.0 \\
\hline Yes & 69 & 60.0 \\
\hline Immediately & 48 & 41.7 \\
\hline Scheduled visit & 21 & 18.3 \\
\hline
\end{tabular}


Table (3a): Health care professional and patient barriers associated with pain management of the studied patients $(n=115)$

\begin{tabular}{|c|c|c|c|c|c|c|}
\hline \multirow{2}{*}{ Barriers associated with pain management } & \multicolumn{2}{|c|}{ Always } & \multicolumn{2}{|c|}{ Sometimes } & \multicolumn{2}{|c|}{ Never } \\
\hline & No. & $\%$ & No. & $\%$ & No. & $\%$ \\
\hline \multicolumn{7}{|l|}{ I. Heath Care Professional Related Barriers } \\
\hline $\begin{array}{l}\text { Waiting list for scheduling consultation is too } \\
\text { long. }\end{array}$ & 81 & 70.4 & 27 & 23.5 & 7 & 6.1 \\
\hline $\begin{array}{l}\text { Pain is routinely assessed during visit by the nurse } \\
\text { or doctor. }\end{array}$ & 26 & 22.6 & 75 & 65.2 & 14 & 12.2 \\
\hline Pain is well managed by the doctor or nurse. & 20 & 17.4 & 81 & 70.4 & 14 & 12.2 \\
\hline $\begin{array}{l}\text { Patients are in pain and it takes time to be } \\
\text { attended. }\end{array}$ & 67 & 58.3 & 24 & 20.9 & 24 & 20.8 \\
\hline $\begin{array}{l}\text { Talking about pain is hard because you are not } \\
\text { understood by the medical professionals. }\end{array}$ & 0 & 0.0 & 6 & 5.2 & 109 & 94.8 \\
\hline $\begin{array}{l}\text { Patients are encouraged to endure as much pain as } \\
\text { possible before resorting to a pain relief measure. }\end{array}$ & 0 & 0.0 & 4 & 3.5 & 111 & 96.5 \\
\hline $\begin{array}{l}\text { Given information by the nurse or doctor on side } \\
\text { effects of pain medication. }\end{array}$ & 13 & 11.3 & 92 & 80.0 & 10 & 8.7 \\
\hline $\begin{array}{l}\text { The side effects of opioids (morphine) are } \\
\text { managed by the doctor. }\end{array}$ & 15 & 13.0 & 55 & 47.8 & 45 & 39.2 \\
\hline $\begin{array}{l}\text { Consultation to supportive care by the medical } \\
\text { professionals is done. }\end{array}$ & 9 & 7.8 & 84 & 73 & 22 & 19.2 \\
\hline \multicolumn{7}{|l|}{ II. Patient related barriers } \\
\hline Worried that pain medications cost too much. & 61 & 53.0 & 11 & 9.6 & 43 & 37.4 \\
\hline Finding transportation means is difficult. & 78 & 67.8 & 9 & 7.8 & 28 & 24.4 \\
\hline $\begin{array}{l}\text { Locating the referral facility is difficult and hence } \\
\text { takes long to get treatment. }\end{array}$ & 30 & 26.1 & 5 & 4.3 & 80 & 69.6 \\
\hline Patients are afraid of reporting the pain. & 1 & 0.9 & 5 & 4.3 & 109 & 94.8 \\
\hline $\begin{array}{l}\text { Worried that having pain is a sign that the illness } \\
\text { has gotten worse. }\end{array}$ & 105 & 91.3 & 6 & 5.2 & 4 & 3.5 \\
\hline $\begin{array}{l}\text { Patients believe that it is better to endure pain } \\
\text { than to lose the breast. }\end{array}$ & 45 & 39.1 & 6 & 5.2 & 64 & 55.7 \\
\hline $\begin{array}{l}\text { Worried of the long term use of pain medications } \\
\text { and being on treatment regularly. }\end{array}$ & 105 & 91.3 & 6 & 5.2 & 4 & 3.5 \\
\hline $\begin{array}{l}\text { Have difficulty understanding information about } \\
\text { pain medication. }\end{array}$ & 13 & 11.3 & 68 & 59.1 & 34 & 29.6 \\
\hline Ashamed of being on treatment regularly. & 102 & 88.7 & 7 & 6.1 & 6 & 5.2 \\
\hline $\begin{array}{l}\text { Patients do not just want to take opioids } \\
\text { (morphine). }\end{array}$ & 32 & 27.8 & 4 & 3.5 & 79 & 68.7 \\
\hline Busy with work or school to see a doctor. & 0 & 0.0 & 9 & 7.8 & 106 & 92.2 \\
\hline
\end{tabular}


Table (3b): System and medication barriers associated with pain management of the studied patients $(\mathbf{n}=115)$

\begin{tabular}{||l|c|c|c|c|c|c||}
\hline \multirow{2}{*}{ Barriers associated with pain management } & \multicolumn{2}{|c|}{ Always } & \multicolumn{2}{c|}{ Sometimes } & \multicolumn{2}{c||}{ Never } \\
\cline { 2 - 6 } & No. & $\mathbf{\%}$ & No. & $\mathbf{\%}$ & No. & \% \\
\hline III. System barriers & & & & & & \\
\hline Drugs especially morphine are not available. & 1 & 0.9 & 31 & 27.0 & 83 & 72.1 \\
\hline $\begin{array}{l}\text { Pharmacists do not issue the drug because the prescription is } \\
\text { not complete. }\end{array}$ & 0 & 0.0 & 12 & 10.4 & 103 & 89.6 \\
\hline Patients are denied the prescribed pain medications. & 0 & 0.0 & 0 & 0.0 & 115 & $\mathbf{1 0 0 . 0}$ \\
\hline Travel long distance to get medication. & 84 & 73.0 & 4 & 3.5 & 27 & 23.5 \\
\hline $\begin{array}{l}\text { Reviewed by different doctors during visit hence no } \\
\text { continuity of care. }\end{array}$ & 109 & $\mathbf{9 4 . 8}$ & 6 & 5.2 & 0 & 0.0 \\
\hline $\begin{array}{l}\text { Patients have to wait for the scheduled return visit to get } \\
\text { your drugs despite being in pain. }\end{array}$ & 63 & 54.8 & 33 & 28.7 & 19 & 16.5 \\
\hline Time allocated to your pain needs by staff is enough. & 37 & 32.2 & 36 & $\mathbf{3 1 . 3}$ & 42 & 36.5 \\
\hline IV. Medication Barriers & & & & & & \\
\hline Pain is relieved by the prescribed pain medication dose. & 19 & 16.5 & 57 & $\mathbf{4 9 . 6}$ & 39 & $\mathbf{3 3 . 9}$ \\
\hline $\begin{array}{l}\text { It is easier to put up with pain than with the side effects that } \\
\text { come from pain medicine. }\end{array}$ & 15 & 13.0 & 19 & 16.5 & 81 & 70.5 \\
\hline Patients report the side effects of the pain medications. & 103 & $\mathbf{8 9 . 6}$ & 12 & 10.4 & 0 & 0.0 \\
\hline $\begin{array}{l}\text { The side effects (nausea, constipation) of pain medicine are } \\
\text { difficult to control. }\end{array}$ & 93 & 80.9 & 12 & 10.4 & 10 & 8.7 \\
\hline Worried of getting addicted to pain medicine. & 104 & $\mathbf{9 0 . 4}$ & 7 & 6.1 & 4 & 3.5 \\
\hline Body has become used to the effects of pain medicine. & 10 & 8.7 & 0 & 0.0 & 105 & 91.3 \\
\hline $\begin{array}{l}\text { Using pain medicine blocks your ability to know if you have } \\
\text { any new pain. }\end{array}$ & 0 & 0.0 & 1 & 0.9 & 114 & $\mathbf{9 9 . 1}$ \\
\hline $\begin{array}{l}\text { Patients believe that using alternative medicine is better than } \\
\text { taking opioids (morphine). }\end{array}$ & 57 & 49.6 & 4 & 3.4 & 54 & 47.0 \\
\hline $\begin{array}{l}\text { Patients believe pain medicine should be taken only when } \\
\text { the pain is severe. }\end{array}$ & 14 & 12.2 & 5 & 4.3 & 96 & 83.5 \\
\hline
\end{tabular}

Table (3c): Sociocultural barriers associated with pain management of the studied patients $(\mathbf{n}=115)$

\begin{tabular}{|c|c|c|c|c|c|c|}
\hline \multirow{2}{*}{ Barriers associated with pain management } & \multicolumn{2}{|c|}{ Always } & \multicolumn{2}{|c|}{ Sometimes } & \multicolumn{2}{|c|}{ Never } \\
\hline & No. & $\%$ & No. & $\%$ & No. & $\%$ \\
\hline \multicolumn{7}{|l|}{ V. Sociocultural Barriers } \\
\hline Family has a role in pain management. & 70 & 60.9 & 5 & 4.3 & 40 & 34.8 \\
\hline $\begin{array}{l}\text { Have a sick family member to take care of preventing you to } \\
\text { attend the clinic. }\end{array}$ & 1 & 0.9 & 44 & 38.3 & 70 & 60.8 \\
\hline $\begin{array}{l}\text { Family/friends make fun of you when you complain about } \\
\text { pain. }\end{array}$ & 12 & 10.4 & 9 & 7.8 & 94 & 81.8 \\
\hline People around you have a negative image of morphine. & 37 & 32.2 & 7 & 6.1 & 71 & 61.7 \\
\hline It is against your religion to seek medical treatment. & 39 & 33.9 & 2 & 1.7 & 74 & 64.4 \\
\hline $\begin{array}{l}\text { People around you believe if you have cancer you should not } \\
\text { go for treatment }\end{array}$ & 111 & 96.6 & 2 & 1.7 & 2 & 1.7 \\
\hline $\begin{array}{l}\text { Your community believe in traditional herbal medicine than } \\
\text { seeking treatment }\end{array}$ & 111 & 96.6 & 2 & 1.7 & 2 & 1.7 \\
\hline $\begin{array}{l}\text { Your friends advised you not to go for treatment because of } \\
\text { their previous experiences with pain medications. }\end{array}$ & 99 & 86.1 & 3 & 2.6 & 13 & 11.3 \\
\hline It is against your culture to talk about pain. & 36 & 31.3 & 1 & 0.9 & 78 & 67.8 \\
\hline
\end{tabular}


Table (4): Mean, standard deviation of barriers associated with pain management of the studied female patients $(n=115)$

\begin{tabular}{|c|c|c|c|c|c|c|c|c|}
\hline \multirow{3}{*}{$\begin{array}{l}\text { Barriers Associated } \\
\text { with Pain Management }\end{array}$} & \multicolumn{8}{|c|}{ Score of barriers (\%) } \\
\hline & \multirow{2}{*}{ Min-Max } & \multirow{2}{*}{ Mean \pm SD } & \multicolumn{2}{|c|}{$\underset{(<45 \%)}{\text { Low }}$} & \multicolumn{2}{|c|}{$\begin{array}{c}\text { Moderate } \\
(45 \%-\leq 65 \%)\end{array}$} & \multicolumn{2}{|c|}{$\begin{array}{c}\text { High } \\
(65 \% \leq)\end{array}$} \\
\hline & & & No. & $\%$ & No. & $\%$ & No. & $\%$ \\
\hline $\begin{array}{l}\text { Heath Care Professional } \\
\text { Related Barriers }\end{array}$ & $33.3-88.9$ & $64.1 \pm 9.7$ & 8 & 7.0 & 48 & 41.7 & 59 & 51.3 \\
\hline Patient related barriers & $33.3-90.9$ & $67.1 \pm 10.9$ & 4 & 3.4 & 41 & 35.7 & 70 & 60.9 \\
\hline System barriers & $38.1-76.2$ & $63.1 \pm 8.2$ & 3 & 2.6 & 58 & 50.4 & 54 & 47.0 \\
\hline Medication Barriers & $33.3-77.8$ & $58.5 \pm 8.9$ & 5 & 4.3 & 83 & 72.2 & 27 & 23.5 \\
\hline Sociocultural Barriers & $40.7-92.6$ & $67.1 \pm 9.7$ & 2 & 1.7 & 51 & 44.4 & 62 & 53.9 \\
\hline Total score & $37.0-76.3$ & $64.1 \pm 6.7$ & 1 & 0.9 & 57 & 49.5 & 57 & 49.6 \\
\hline
\end{tabular}

Table (5): Relation between Bio socio-demographic characteristics and the level of barriers experienced by the studied female patients $(n=115)$

\begin{tabular}{|c|c|c|c|c|c|}
\hline \multirow{3}{*}{$\begin{array}{l}\text { Bio socio demographic } \\
\text { characteristics }\end{array}$} & \multicolumn{4}{|c|}{ Level of barriers } & \multirow{3}{*}{ Significance } \\
\hline & \multicolumn{2}{|c|}{ Low/moderate $(n=58)$} & \multicolumn{2}{|c|}{$\begin{array}{l}\text { High } \\
(\mathrm{n}=57)\end{array}$} & \\
\hline & No. & $\%$ & No. & $\%$ & \\
\hline \multicolumn{6}{|l|}{ Age (years) } \\
\hline$<40$ & 12 & 54.5 & 10 & 45.5 & $\chi^{2}=5.610$ \\
\hline $40-$ & 27 & 41.5 & 38 & 58.5 & $\stackrel{n}{\mathrm{P}}=0.061$ \\
\hline $50-\leq 60$ & 19 & 67.9 & 9 & 32.1 & \\
\hline \multicolumn{6}{|l|}{ Marital status } \\
\hline Single & 11 & 47.8 & 12 & 52.2 & \\
\hline Married & 32 & 62.7 & 19 & 37.3 & $\chi^{2}=6.400$ \\
\hline Divorced & 5 & 33.3 & 10 & 66.7 & $\mathrm{P}=0.094$ \\
\hline Widow & 10 & 38.5 & 16 & 61.5 & \\
\hline \multicolumn{6}{|l|}{ Living arrangement } \\
\hline Live with spouse/children & 15 & 51.7 & 14 & 48.3 & $\chi^{2}=2.580$ \\
\hline Live alone & 11 & 37.9 & 18 & 62.1 & $\mathrm{P}=0.276$ \\
\hline Live with spouse children & 32 & 56.1 & 25 & 43.9 & \\
\hline \multicolumn{6}{|l|}{ Educational level } \\
\hline Illiterate & 9 & 75.0 & 3 & 25.0 & \\
\hline Primary education & 7 & 31.8 & 15 & 68.2 & $\chi^{2}=8.525$ \\
\hline High school & 23 & 45.1 & 28 & 54.9 & $\mathrm{P}=0.036 *$ \\
\hline College/ Graduate & 19 & 63.3 & 11 & 36.7 & \\
\hline \multicolumn{6}{|l|}{ Employment status } \\
\hline Employed & 23 & 59.0 & 16 & 41.0 & $\chi^{2}=1.722$ \\
\hline Not employed & 35 & 46.1 & 41 & 53.9 & $\mathrm{P}=0.189$ \\
\hline \multicolumn{6}{|l|}{ Health insurance } \\
\hline Yes & 50 & 51.0 & 48 & 49.0 & $\chi^{2}=0.091$ \\
\hline No & 8 & 47.1 & 9 & 52.9 & $\mathrm{P}=0.763$ \\
\hline \multicolumn{6}{|l|}{ Monthly income } \\
\hline Insufficient & 17 & 35.4 & 31 & 64.6 & $\chi^{2}=7.430$ \\
\hline Sufficient/more & 41 & 61.2 & 26 & 38.8 & $\stackrel{\tilde{P}=0.006 *}{ }$ \\
\hline
\end{tabular}

$X^{2}$ : Chi-Square test $\quad{ }^{M C} P:$ Monte Carlo corrected $P$-value $\quad$ *significant at $P \leq 0.05$ 
Table (6): Relation between level of barriers experienced and the clinical characteristics of the studied female patients $(n=115)$

\begin{tabular}{|c|c|c|c|c|c|}
\hline \multirow{3}{*}{ Clinical characteristics } & \multicolumn{4}{|c|}{ Level of barriers } & \multirow{3}{*}{ Significance } \\
\hline & \multicolumn{2}{|c|}{$\begin{array}{c}\text { Low/moderate } \\
(n=58)\end{array}$} & \multicolumn{2}{|c|}{$\begin{array}{l}\text { High } \\
(n=57)\end{array}$} & \\
\hline & No. & $\%$ & No. & $\%$ & \\
\hline \multicolumn{6}{|l|}{ Stage of disease } \\
\hline Stage III & 7 & 87.5 & 1 & 12.5 & $\chi^{2}=9.928$ \\
\hline Stage IV & 42 & 54.5 & 35 & 45.5 & ${ }^{\mathrm{MC}} \mathbf{P}=\mathbf{0 . 0 0 6} *$ \\
\hline Inflammatory & 9 & 30.0 & 21 & 70.0 & \\
\hline \multicolumn{6}{|l|}{ Current status of disease } \\
\hline Newly diagnosed & 2 & 22.2 & 7 & 77.8 & $\chi^{2}=21.246$ \\
\hline Under treatment & 37 & 71.2 & 15 & 28.8 & ${ }^{\mathrm{MC}} \mathbf{P}<0.0001 *$ \\
\hline Recurrent under treatment & 15 & 30.6 & 34 & 69.4 & \\
\hline Others & 4 & 80.0 & 1 & 20.0 & \\
\hline \multicolumn{6}{|l|}{ Previous treatment } \\
\hline Surgery & 38 & 56.7 & 29 & 43.3 & $\chi^{2}=4.400$ \\
\hline Chemotherapy/radiotherapy & 14 & 50.0 & 14 & 50.0 & $\mathrm{P}=0.111$ \\
\hline Herbal medicine & 6 & 30.0 & 14 & 70.0 & \\
\hline \multicolumn{6}{|l|}{ Current treatment } \\
\hline Chemotherapy & 54 & 49.5 & 55 & 50.5 & ${ }^{\mathrm{FE}} \mathrm{P}=0.679$ \\
\hline Radiotherapy/both & 4 & 66.7 & 2 & 33.3 & \\
\hline \multicolumn{6}{|l|}{ Seek medical advice when in pain } \\
\hline No & 16 & 34.8 & 30 & 65.2 & $\chi^{2}=7.514$ \\
\hline Yes & 42 & 60.9 & 27 & 39.1 & $P=0.006 *$ \\
\hline Timing of the seeking medical advice & $(\mathrm{n}=42)$ & & $(\mathrm{n}=27)$ & & \\
\hline Immediate & 31 & 64.6 & 17 & 35.4 & $\chi^{2}=0.913$ \\
\hline Scheduled & 11 & 52.4 & 10 & 47.6 & $\mathrm{P}=0.339$ \\
\hline \multicolumn{6}{|l|}{ Visual analogue scale (VAS) } \\
\hline Mild/moderate pain & 41 & 70.7 & 17 & 29.3 & $\chi^{2}=19.200$ \\
\hline Severe pain & 17 & 29.8 & 40 & 70.2 & $\mathbf{P}<0.0001 *$ \\
\hline
\end{tabular}

$X^{2}$ : Chi-Square test $\quad{ }^{M C} P$ : Monte Carlo corrected P-value ${ }^{F E} P$ : Fisher's exact test $\quad *_{\text {significant at } P \leq 0.05}$ 


\section{References}

1. American Cancer Society. Cancer Facts \& Figures 2016. Atlanta: American Cancer Society; 2016.

2. Diaconu C, Pantis C, Cirimbei C, et.al. PainAssociated Biomarkers in Breast Cancer. J Med Life. 2015; 8(1):32-6.

3. Islam E, Payne J. Metastatic Breast Cancer. Mayo Clin Proc. 2015; 90(4):560.

4. American Cancer Society. Breast Cancer Facts \& Figures 2015-2016. Atlanta: America Cancer Society; 2015.

5. Kisuya J, Wachira J, Busakhala N, et.al. Impact of an Educational Intervention on Breast Cancer Knowledge in Western Kenya. Health Educ Res. 2014; 30(5):786-96.

6. Meredith S. Disparities in Breast Cancer and the Role of Patient Navigator Programs. Clin J Oncol Nursing. 2013; 17(1):54-9.

7. Cardoso F, Costa A, Senkus E, et.al. 3rd ESO ESMO International Consensus Guidelines for Advanced Breast Cancer. Ann Oncol. 2017; 28(12):16-33.

8. Beck S, Falkson G. Prevalence and Management of Cancer Pain in Ambulatory Patients Kenyatta National Hospital. 2001; 94(1):75-84.

9. Paice J, Ferrell B. The Management of Cancer Pain. J Clin. 2011; 61(3):157-82.

10. Breivik H, Borchgrevink P. Assessment of Pain. In: Assessment of Pain. 2008. Available at: http://www.nursingtimes.net/nursingpractice/specialisms/painmanagement/assessment-of-pain. Accessed on: 23 October 2017.

11. Doyle B. Pain as the Fifth Vital Sign. Nurs J India. 2014; 3(11):36-9.

12. The British Pain Society. Cancer Pain Management. London; 2013. Available at: www.britishpainsociety.org. Accessed on: 23 October 2017.

13. Shute C. The Challenges of Cancer Pain Assessment and Management. Ulster Med J. 2013; 82(1):40-2.
14. Valeberg B. Pain, Coping, and Barriers to Pain Management in Outpatients with Cancer. Bergen, Norway; 2009.

15. Jacobsen R, Liubarskiene Z, Claus $M$ et al. Barriers to Cancer Pain Management: A Review of Empirical Research. Medicina (B Aires). 2009; 45(6):427-33.

16. Cherny N, Baselga J, Conno F, et.al. Formulary Availability and Regulatory Barriers to Accessibility of Opioids for Cancer Pain in Europe: A report from the ESMO/EAPC opioid policy initiative. Ann Oncol. 2010; 21(3):61526.

17. Duignan M, Dunn V. Barriers to Pain Management in Emergency Departments. Emerg Nurse. 2008; 15(9):30-4.

18. Medical Board of California. Guidelines for Prescribing Controlled Substances for Pain Medical Board of California. 2014. Available at: http://www.mbc.ca.gov/licensees/prescribing/pai

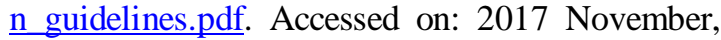
13.

19. Donkor A. Factors Contributing to Late Presentation of Breast Cancer in Africa: A Systematic Literature Review. Arch Med. 2015; 8(22):1-10.

20. National Breast Cancer. Specialist Breast Nurses: an Evidence-Based Model for Australian Practice. [Australia]; 2000. Available at:

http://www.nbcc.org.au/pages/info/resource/nbcc pubs/nbccpubs.htm. Accessed on: 2017 November, 13.

21. Odusanya O, Tayo O. Breast Cancer Knowledge, Attitudes and Practice among Nurses in Lagos, Nigeria. Acta Oncol (Madr). 2001; 40(7):844-8.

22. Smeltzer S, Janice H, Brenda B, et.al. Brunner \& Suddarth's textbook of medical-surgical nursing. 12th ed. Philadelphia: Wolters Kluwer Health / Lippincott Williams \& Wilkins; 2010. P.336391.

23. Unger-Saldaña K, Peláez-Ballestas I, InfanteCastañeda C. Development and validation of a Questionnaire to Assess Delay in Treatment for Breast Cancer. BMC Cancer. 2012; 12:626-39. 
24. Valeberg B, Hanestad B, Klepstad P, et.al. Cancer Patients' Barriers to Pain Management and Psychometric Properties of the Norwegian Version of the Barriers Questionnaire II. Scand J Caring Sci. 2009; 23(3):518-28.

25. Jacobsen R, Moldrup L, Christrup P, et.al. The Danish Version of the Questionnaire on Pain Communication: Preliminary Validation in Cancer Patients. Acta Anaesthesiol Scand. 2009; 53(6):807-15.

26. Bourdeanu L, Luu T, Baker N, et.al. Barriers to treatment in patients with locally advanced breast cancer. J Natl Compr Canc Netw. 2013; 11(10):1193-8.

27. Klimek L, Tilo KB, Jean B, Peter B, Kirsten H, Merk H, et al. Visual analogue scales ( VAS ): Measuring Instruments for the Documentation of Symptoms and Therapy Monitoring in Cases of Allergic Rhinitis in Everyday Health Care. Allergo J Int. 2017; 26:16-24.

28. Sorana B, Jäntschi L, Adriana S, et.al. PearsonFisher Chi-Square Statistic. Information 2011; 2:528-45.

29. Ismail G, Abd El Hamid A, Abd ElNaby A. Assessment of Factors that Hinder Early Detection of Breast Cancer among Females at Cairo university hospital. World Appl Sci J. 2013; 23(1):99-108.

30. Hughes E, Zirimenya L, Merriman A. Pain in Advanced Breast Cancer in Uganda. JSM Pain Manag. 2017; 2:1-5.

31. American Cancer Society. Breast Cancer Facts \& Figures 2017-2018. Atlanta: American Cancer Society; 2017.
32. Lim H. Factors Influencing Late Stage of Breast Cancer at Presentation in a District Hospital Segamat Hospital, Johor. 2015; 70(3):148-52.

33. Kwon J. Overcoming Barriers in Cancer Pain Management. J Clin Oncol. 2014; 32(16):172733.

34. Hum S, Wu M, Pruthi S, et.al. Physician and Patient Barriers to Breast Cancer Preventive Therapy. Curr Breast Cancer Rep. 2016; 8(3):158-64.

35. Norsa'adah B, Rahmah M, Rampal K, et.al. Understanding Barriers to Malaysian Women with Breast Cancer Seeking Help. Asian Pacific J Cancer Prev. 2012; 13:3723-30.

36. Liu Y, Zhang J, Huang R, et.al. Infl uence of Occupation and Education Level on Breast Cancer Stage at Diagnosis, and Treatment Options in China. Medicine (Baltimore). 2017; 15(3):1-9.

37. Wang Q, Li J, Zheng S, et.al. Breast Cancer Stage at Diagnosis and Area-Based Socioeconomic Status: A Multicenter 10-Year Retrospective Clinical Epidemiological Study in China. BMC Cancer. 2012; 12(1):122.

38. Stuver S, Isaac T, Weeks JC, et.al. Factors Associated With Pain Among Ambulatory Patients Cancer Center. J Oncol Pract. 2016; 8(4):17-23.

39. Citrin D, Kapustin J. How Can Nurses Best Help Women Facing Breast Cancer? Nurs Palliat Care. 2016; 1(2):38-40. 